\title{
Mapping Imperial Fantasy
}

\author{
An Encounter with: \\ Mark Kingwell. Nearest Thing to Heaven: The Empire State Building and \\ American Dreams. New Haven, CT: Yale University Press, 2006. 256 pages. \\ TRACEY NiCHOLlS
}

Mark Kingwell's latest book is an engaging and loving tribute to New York City's Empire State Building, arguably the most famous and widely recognized building in the United States. His book takes its title from a line in the film An Affair to Remember, one of the first to depict the building as a site of meeting or reunion for couples whose lives are transformed by 'true love'; the female lead responds to her lover's suggestion that they meet again in six months at the top of the building with the enthusiastic observation that his choice is perfect because "it's the nearest thing to heaven we have in New York!" (172). Kingwell's analysis of the Empire State Building ranges over the history of its construction, its life as an office building and a tourist attraction, and its presence in our cultural landscape, tracing the "dynamic between longing and visibility" the building exemplifies (ix). While he provides a comprehensive account of the complex and enduring relationship the building has had with the city since its inception, Kingwell pays particular attention to how, having previously faded into a kind of invisibility because of its familiarity, the building has re-emerged as visible since the abrupt and tragic removal of the World Trade Center buildings (ix). Kingwell describes his book as "concerned 
with vanishings, failures, deceptions, and distortions - the strange things that swirl around the building, like windblown paper after a traumatic event" (x).

The book argues that the Empire State Building had an unrivalled hold on New York's imagination from the start, outstripping any claim to symbolizing the city that the World Trade Center was ever able to make (11). The Empire State Building was, Kingwell tells us, the first megaproject, built to inspire hope in a nation gripped by the economic desperation that followed the Stock Market Crash of 1929 (2). Thanks to cheap labour and a desperate, Depression-era workforce, the building was unusual from the start, a construction project completed ahead of schedule and significantly under budget (3). It was also a public relations triumph, instantly mythologized as the world's tallest building (8). Picking up Walter Benjamin's characterization of Paris as the capital of the nineteenth century, Kingwell argues for a similar characterization of New York - capital of the twentieth century, and capital of the world - and for a view of the Empire State Building as "sign and ambassador" of this seat of postmodern empire (19). The building's hold on America's imagination, and its central place in imaginings of America, began with its status as an architectural and engineering achievement but has since expanded to occupy a claim to being the wonder of the modern world, a cultural landmark Kingwell designates "a cathedral ... of Americanness" (33). Comparing the relative symbolic values of New York City's most famous buildings, he tells us that, "[e]xcept in the pathological imagination of a terrorist, the World Trade Center never really symbolized anything, except the bland face of latetwentieth-century capitalism" (11). Kingwell's assertion of this primary status the Empire State Building merits within a pantheon of American landmarks has a certain historical plausibilityat least until now, when, paradoxically, the cityscape seems to be marked by the absence of the twin towers. ${ }^{1}$ But his practical consideration of the relative fragility of glass and steel towers 
versus a brick, steel and limestone skyscraper (12) suggests an interesting insight: perhaps the things we love most are less fragile than we fear they are, and perhaps the things that make Western nations most a target for contemporary terrorist movements are peripheral to our selfconcept anyway.

It is the frequent occurrence of these sorts of insights that make this book so much more than just a tribute to a building, however renowned it may be. What makes it of particular interest to philosophers is that Kingwell does not limit his investigation to cultural history, insisting instead that we explore with him the metaphysical and political significance of both this building in particular and the skyscraper in general. We delve into these questions through an extended discussion of the building's capacity to function as an icon. Kingwell defines an icon as "a special kind of visual sign that takes its place within an economy of political meaning," a coded representation (43). As he presents it, the Empire State Building's distinctive iconic status is two-fold: it reinforces the democratic myth that the American dream is accessible to everyone, and it is an endlessly changeable site of multiple meanings $(35,21)$. "Its relation to the coded narratives of Americanness and the dream of liberation are constantly unstable, renewed and upset at every moment," Kingwell notes (21). What we see when we look at the building is not the building itself but the cultural values we attach to it; this is the sense in which Kingwell thinks the building retreats into invisibility and permits the emergence of an "automonument," a building which asserts its own monumentality (40-41, 15). Although Kingwell does not explicitly connect his discussion of monumentality to Arthur Danto's, the comparison is instructive for what it suggests about the difference between the Empire State Building and the World Trade Center. Danto distinguishes monuments, which we build in order to remember, from memorials, which we build in order that we not forget (see "The Vietnam Veterans 
Memorial"). The World Trade Center may once have been a monument—to late-stage capitalism, in the eyes of the terrorists who destroyed it-but whatever takes its place on the newly-dubbed 'ground zero' will always have the character of a memorial. The Empire State Building, on the other hand, will always be a symbol of New York City, one that embodies Americanness to each of us. Paraphrasing Voltaire, Kingwell insists that "[i]f the Empire State building did not exist, we would have to invent it" (20-21).

And we would indeed have the drive to invent it: Kingwell hypothesizes that we build skyscrapers in a quest for height that is, at its core, a desire for transcendence or control, such that the view from the tower is simply an achievable variation of an impossible "view from nowhere" (50). The view from above, which gives us the illusion that we are seeing all there is to see, is ultimately a dangerous fiction because always hidden from our view is the infrastructure-pipes, wires, cables — that, as Heidegger notes of the 'ready-to-hand' in Being and Time, becomes conspicuous in its moments of breakdown and failure to function (52). These hidden, unknown aspects of buildings, their insides, their function as office buildings, are also suggestive of a common defect in analyses of empire: most look at it from outside, and fail to consider the view from inside as an integral part of the account. Because we buy in to the error of thinking about buildings as outsides and elevated viewing platforms, we objectify the Empire State Building rather than inhabiting it. This, coupled with the building's iconic status, leads us to create an elaborate tourist economy of taking pictures, buying postcards, and participating in other ways of representing the building (120). These activities makes the building invisible: people don't see it so much as they engage in the experience of capturing it, and the activity of documenting their tourist visit with their own personal representations (photographs) or commercialized representations (souvenirs) becomes their focal point (120). Kingwell argues 
that commercialization of these various means of representation form a counterexample to Walter Benjamin's assertion that mechanical reproduction would liberate artworks and audiences from the elitism and authority, the aura, of the singular authentic artwork (see "The Work of Art in the Age of Mechanical Reproduction"). The more widely representations of the building are reproduced, the more flawless the reproductions become and the more authoritatively they reinforce the aura of the work or object, even as they inextricably place the work or object in a network of commercial relations (Kingwell 139-140). Ultimately, neither models, a priori images, nor pictures, a posteriori images, give us the essence of the building; representation, however accurate it may seem, is still just a copy and, because of differences in size and dimensionality, will never be entirely veridical (159). So if we ask what the essence of a building is, we are left with the seeming inadequacy of any answer (103): it is not the mere physical structure or the function of the building-neither of these fully capture the Empire State Building's essence_-but if we posit the building's iconic status as its essence, we are left with the problem of its symbolic multiplicity. This suggests a pluralism or subjectivism in Kingwell's metaphysics, a suggestion reinforced by his notion of buildings as processes, not objectsperformative, dynamic, active (16), and his claim that, as a 'gestural' building, the Empire State Building is "an ongoing aesthetic performance" (92).

To the extent that we can answer this metaphysical question of essence, it would seem that we need to seek our answer in political considerations. Even the name, 'Empire State' (after New York State's nickname), "has a new resonance in the political realities of the twenty-first century ... now that The United States assuredly is an empire, albeit of an unusual postmodern sort, the building has a central place in the economy of meaning centered on the idea of "America"' (14). When we ponder this resonance along with the symbolic meaning of the 
skyscraper, we see that even the practical justification of building up when one cannot build out does not remove the symbolic meaning of the platform, the desire to conquer and control (56).

Like an empire, "[t]he building is there for all to see, but only for some to use, and only in the prescribed ways" (59). And, Kingwell tells us, all aspects of architecture are "through and through political" (109), a point reinforced by contestations of public space that derive from people's desire to claim shared public spaces as private spaces-as was the case, for instance in the 2002 conflict between Jewish and Palestinian students at Concordia University which resulted in pro-Palestinian students occupying escalators in the main foyer as part of a direct action campaign to shut down a Hillel-organized speaking engagement by controversial former Israeli Prime Minister Benjamin Netanyahu. ${ }^{2}$ Ironically, contestations within and about public space frequently, as in the Concordia case, arise precisely because people do not understand their public spaces as political, mistakenly believing (at least some of) them to have some sort of neutrality. Part of the reason why we experience spaces as political without necessarily articulating them as such is that, often, the vehicles of our awareness are visual. Kingwell offers, for instance, an extended discussion of the ways in which the Empire State Building has been presented in film and observes that it is a curious fact of our postmodern age that the things we see on screen are often more influential and more emotionally powerful than our real-life experiences (168). The desires and lifestyles that are packaged for us in films play a key role in our identity-formation and our need to construct narratives as a way of investing our lives with meaning (171). Kingwell mentions in particular cinematic representations of the Empire State Building of the future, complete with airship docking stations, and, parsing nostalgia as longing not just for a past we hope to return to but also for a future we had previously envisioned, he links a desire to colonize the sky with a desire to colonize the future (182-185). 
Kingwell contends that 9/11 marked not just a new appreciation for Empire State Building but an examination of the coincidence of the building's name, the state's nickname, and the nation's political status (194). While the appreciation may be new, he argues, the coincidence is not and, to illustrate his point, he draws a comparison between the mobilization of materials and labour that went into constructing the building and the resources that were channelled into "the emergent war machine of the late 1930s" (194). He quotes a 1933 prediction of a war, with either Japan or Latin America, seen as the only workable alternative to chaos and revolution that would follow from a failure of Roosevelt's New Deal, and observes that this prediction turns out to be true of later wars: "The national press is primed; war will be accepted as natural and inevitable" (195). Kingwell understands the imperial nation as a machine, a system that functions underneath the surface of national discourse and is driven by constant demands to be fuelled (196). Like a coal engine requiring a man's unceasing labour to feed it, "the United States is locked in a condition subordinate ... to [its] ceaseless demands from inside," says Kingwell, and it does its greatest damage not to the peoples of the nations upon which it imposes military occupation, but to its own citizens (196). Part of the damage it does is to society's sense of solidarity and civil liberties, as can be seen "when citizens utter the sentiment, so often heard of late, that if you have nothing to hide, you have nothing to fear," a sentiment motivated by the naïve belief that it will be obvious to those tasked with national security who are the innocent, protection-worthy citizens and who are the guilty alien others (197). The 'security machine' that is perpetuated by this sentiment functions as a panopticon, an internalized self-surveillance (197). This self-surveillance impulse is encoded in the experience most people have of the Empire State Building: they buy tickets, wait in line, and take multiple elevators to the top in order to look down at the place in the city where they were before, and to which they will return 
(202). Like our postmodern empire, the building Kingwell deconstructs for us "seems fixed and immobile, a monolith; in fact, though, it is fluid and airy, many things to many people," those within and those outside (201). Read simply as a billet-doux to a mesmerizing and historically significant landmark, the book is a witty and literate delight but, in my view, the enduring value of Kingwell's thoughtful and interdisciplinary study of the building he loves with such evident sincerity is the impressive job it does of showing how the architecture that constructs the backdrop of our everyday lives also reveals our philosophical and political context.

\section{Notes}

${ }^{1}$ See, for example, Dratel 114; a view reinforced by part of the planned memorial, "Reflecting Absence," which, according to the judges of the World Trade Center Site Memorial Competition, "has made the voids left by the destruction the primary symbols of our loss" (http://www.wtcsitememorial.org/).

${ }^{2}$ See Discordia, dir. Samir Mallal and Ben Addelman, National Film Board of Canada, 2004.

\section{Other Works Cited}

Benjamin, Walter. "The Work of Art in the Age of Mechanical Reproduction." Illuminations. Ed. Hannah Arendt. Tr. Harry Zorn. New York: Schocken Books, 1969. 217-51.

Danto, Arthur C. “The Vietnam Veterans Memorial," The Nation (August 31, 1985).

Dratel, Joshua. "The Curious Debate." The Torture Debate in America. Ed. Karen J. Greenberg. New York: Cambridge, 2006.

Heidegger, Martin. Being and Time. Tr. Macquarrie and Robinson. Harper \& Row Pub., 1962. 